\title{
Correction to: An Integrated In Vitro-In Silico Approach for Silver Nanoparticle Dosimetry in Cell Cultures
}

\author{
Daniele Poli, ${ }^{1}$ Giorgio Mattei ${ }^{2}$ Nadia Ucciferri, ${ }^{1}$ and Arti Ahluwalia $\mathbb{D}^{1,2}$ \\ ${ }^{1}$ Research Center E. Piaggio, University of Pisa, Pisa, Italy; and ${ }^{2}$ Department of Information Engineering, University of Pisa, Pisa, Italy
}

\section{Correction to: \\ Annals of Biomedical Engineering (2020) \\ https://doi.org/10.1007/s10439-020-02449-5}

The article An Integrated In Vitro-In Silico Approach for Silver Nanoparticle Dosimetry in Cell Cultures, written by Ahluwalia et al., was originally published electronically on the publisher's internet portal (currently SpringerLink) on 13 January 2020 without open access. With the author(s)' decision to opt for Open Choice the copyright of the article changed on 29 January to (c) The Author(s) 2020 and the article is forthwith distributed under a Creative Commons Attribution 4.0 International License (http s://creativecommons.org/licenses/by/4.0/), which permits use, sharing, adaptation, distribution and reproduction in any medium or format, as long as you give appropriate credit to the original author(s) and the source, provide a link to the Creative Commons licence, and indicate if changes were made.
Address correspondence to Arti Ahluwalia, Research Center E. Piaggio, University of Pisa, Pisa, Italy. Electronic mail: arti.ahluwalia@unipi.it The original article can be found online at https://doi.org/10. 1007/s10439-020-02449-5.

\section{OPEN ACCESS}

This article is licensed under a Creative Commons Attribution 4.0 International License, which permits use, sharing, adaptation, distribution and reproduction in any medium or format, as long as you give appropriate credit to the original author(s) and the source, provide a link to the Creative Commons licence, and indicate if changes were made. The images or other third party material in this article are included in the article's Creative Commons licence, unless indicated otherwise in a credit line to the material. If material is not included in the article's Creative Commons licence and your intended use is not permitted by statutory regulation or exceeds the permitted use, you will need to obtain permission directly from the copyright holder. To view a copy of this licence, visit http://crea tivecommons.org/licenses/by/4.0/.

Publisher's Note Springer Nature remains neutral with regard to jurisdictional claims in published maps and institutional affiliations. 